\title{
Socio-Economic Development of the Republic of Uzbekistan for Years of Independence
}

\author{
Salimov Sh* \\ Scientific researcher, Tashkent, Uzbekistan \\ Submission: September 21, 2018; Published: November 19, 2018 \\ "Corresponding author: Salimov Sh, Scientific researcher, Tashkent, Uzbekistan
}

\begin{abstract}
The paper scrutinizes the conceptual descriptions and evaluation of sustainable development of Uzbekistan with the status quo of economic analyses and its sectoral overview as whole. As the objectives, descriptions of the concept of sustainable development are analyzed and classified through current theoretical views. Furthermore, analysis the systematic view of the dimensions of sustainable development is provided while methods of systematic scientific literature analysis, general and logical analysis, comparison and generalization were used for the research. Investigation concludes with sustainability issues with analyzes and solution on the system levels where they develop and manifest themselves, one can consistently formulate respective aims of the sustainable development policy for separate dimensions (economic, ecological, social, and institutional) of sustainable development on each of these levels of economic development policy, thus obtaining the complex of the aims of sustainability policy.
\end{abstract}

Keywords: Sustainability; Economy of Uzbekistan; Infrastructure; Central asia, Economic competitiveness

\section{Introduction}

The well-known political scientist Leonid Levitin once said: «The appearance of Islam Karimov at the helm of the country can be compared to some extent with Winston Churchill's coming to the leadership of Britain in 1940, at a time that was disastrous for it. Churchill then said in his speech in the House of Commons of the English Parliament: "I have nothing to offer but blood, toil, tears and sweat. We have before us an ordeal of the most grievous kind. We have before us many, many long months of struggle and suffering. ... You ask, what is our aim? I can answer in one word: It is victory, victory at all costs, victory in spite of all terror, victory, however long and hard the road may be; for without victory, there is no survival. ... I feel sure that our cause will not be suffered to fail among men » [1].

After the collapse of the USSR, the situation in Uzbekistan, as well as in the entire post-Soviet space, characterized by a sharp decline in the economy. It caused due to the disruption of economic, industrial and financial ties that had been developed over many years, as well as the legal vacuum of the current legislation and nihilism among a part of the population that were the result of a drastic departure from both the previously dominant communist ideology and the system of values connected with it. As a result, the country had been suffering from runaway inflation as well as from sharp fall in real incomes of the population and increasing number of unemployed ones. Foodstuffs and essential goods were catastrophically not enough.

Outbursts of interethnic and interethnic conflicts had started to plague our country. All this was aggravated by the growth of radicalization especially among young people, as well as by the ongoing military confrontation in Afghanistan and the commenced civil war in Tajikistan.

Such challenges were inherited by the First President of the Republic of Uzbekistan Islam Karimov. Moreover, it is thanks to his unique personal qualities of leader, iron will, unprecedented patriotism and consistently pursued thoroughly thought-out policy that he managed to prevent the country from sliding down into a state of chaos and preserve the peace in it and unity of its people.

Perhaps he was the first and the only one among the leaders of the CIS countries who argued: «Shock therapy is unacceptable for us, we cannot see in people only a means to an end, even a good end. I will not allow people to feel hungry and cold, so that the existing system of social support for the population would be destroyed, so that patients would be left without hospitals and children without schools».

History tells us that exactly at its sharp bends during a change of social formations, social problems and contradictions acquire the most acute character and serve as a potential factor of threats to national security, civil peace and stability. In these regards, Islam Karimov determined the strategy of political and economic development, state and public construction of Uzbekistan based on the historically formed national and cultural traditions of our people and a sober assessment of the country's potential as well as major socio-political and economic trends. This was a deliberate and unequivocal choice - moving towards a modern democratic State with a market economy neither by great leaps nor by revolutionary destruction, but wisely and consistently. 
The first and perhaps the most important postulate of the President Islam Karimov's strategy for the transition period was a cautious and thoughtful implementation of reforms aimed at minimizing the social losses of the population. He formulated it as follows: «One of the leading principles on which Uzbekistan's own way of renewal and progress is based is the implementation of a strong social policy... Provision of reliable social guarantees and social protection measures is a cross-cutting priority at all stages of market transformations and permeates other directions of the whole vast process of society renewal» [2].

The second postulate of his strategy was to ensure sociopolitical and socio-economic stability in the country, as a necessary condition for the successful performing democratic and economic reforms. Islam Karimov's thesis «Do not destroy the old house unless you have built a new one», means do not rashly and suddenly abandon the old proven system before creating a new more effective one. Again, in the matter of reform, gradualness and steadiness are essential.

One of the first Islam Karimov's practical steps of implementing his strategy of reforming the country and laying the foundation for national statehood was the development and adoption in the historically shortest possible time of the country's Basic Law - the Constitution of the Republic of Uzbekistan. Islam Karimov chaired a commission on working out a new Constitution and took an immediate part in the development and consolidation of the basic principles of Nation-building and society development of the country. The most important of them are the following:

a) State expresses the will of the people, serves interests of the people;

b) People of the country are all citizens of Uzbekistan regardless of their nationality;

Equality of all citizens before the law without distinction of gender, race, nationality, language, religion, social origin, convictions, personal and social status.

The Constitution enshrines State guarantees for the freedom of economic activity, entrepreneurship and labor; equality and legal protection and inviolability of all forms of property, including private property; as well as the division of state power into legislative, executive and judicial, the task of forming an integrated system of judicial power had been accomplished successfully.

Important attention was paid to the development and strengthening of the system of local self-government bodies - the «Mahalla» Institution. Indigenous Armed Forces and a system of National security agencies were built up ensuring reliable protection of sovereignty, constitutional order, territorial integrity, public order as well as counteraction to the growing threat of international terrorism, extremism and drug aggression.

Legislative acts «On the Military Doctrine of the Republic of Uzbekistan», «On the Concept of National Security of the Republic of Uzbekistan» and a number of other acts were adopted based on a deep analysis of the socio-political situation in the region and the country's security. That created a solid legal basis for the integrated defense and security system functioning, which contributes to the maintaining of peace, tranquility and stability in the country. President Karimov also focused on issues related to the formation of civil and public institutions, such as the Parliamentary Ombudsman, the National Center for Human Rights and a number of others.

Under the leadership of President Islam Karimov, the Concept of Foreign Policy of the Republic of Uzbekistan was developed based on peacefulness and non-interference in the internal affairs of other states, and the peaceful, settle any disputes and conflicts only by political and peaceful means. The National Parliament approved this document in 2012.

Islam Karimov has repeatedly stated that Uzbekistan firmly adheres to the position to settle any disputes and conflicts only by political and peaceful means, without joining any military-political blocs, not allowing the deployment neither foreign military bases on the territory of its country nor our soldiers outside of Uzbekistan.

He always stressed, «Our people need peace and tranquility. This is the desire of the people of Uzbekistan and the goal of our Nation and its firm decision». After gaining Independence, an active foreign policy Uzbekistan was carried out under the leadership of the First President. Islam Karimov also repeatedly performed his speeches at sessions of the UN General Assembly and other international organizations, presenting his own, sometimes extraordinary, but always honest, heartfelt approach to resolving the most pressing international issues.

His proposals on combining efforts to the fight terrorism and drug trafficking, as well as on the formation of in the Central Asia a so called «Security Belt» were embodied by the opening in Uzbekistan the headquarters of the Regional Antiterrorist Structure (RATS) of the Shanghai Cooperation Organization (SCO)., as well as the creation in Central Asia nuclear weapons free zone from.

Uzbekistan was one of the founder states of the SCO and has already chaired this Organization twice. Thus, in June 2016 in Tashkent, during the Presidency of the Republic of Uzbekistan in the Shanghai Cooperation Organization, a meeting of the Council of Heads of State of the SCO member States was hosted. Important documents and decisions were adopted to improve the SCO activities and to expand further their cooperation in various areas.

Speaking about Central Asia, Islam Karimov noted that the geopolitical space that we call Central Asia, which the world has forgotten about for almost a century, now declares itself in a new capacity, and this causes extraordinary changes in the political situation. At the same time, Central Asia, where the political and economic interests of many countries are concentrated today, is becoming an important and decisive element in shaping the strategy of their foreign policy course.

Director of the Institute of Central Asia, Frederick Star, one of the leading American experts on the problems of this region, 
thinks that «among the Central Asian states only Uzbekistan has every reasons to claim the role of a regional stabilizing force» [3].

The creation of a legal framework for a market economy was the most important basis for the independent development of the country and one of the fundamental moments of economic reform in Uzbekistan. President Islam Karimov believed that «only if there is a strong legal basis we can build a new society with a civilized market economy» [4].

Comprehensive reforms carried out by Islam Karimov brought the consistent implementation and deepening of structural transformations in the economy, sustainable and smooth operations of all of its financial institutions and real economy, promoted the wide introduction of market mechanisms, diversification, continuous technical and technological renewal and development of industrial production, as well as attracting significant-scale investments, including foreign ones. All of these contributed to building the essential capacities, increasing the country's competitiveness, laying a solid foundation for further sustainable development of the Nation.

Brand new high-tech sectors such as petrochemical and automobile industry had been created in the country. Pharmaceutical, chemical industry, agricultural and railway machinery, as well as the production of electrical engineering, textiles and modern construction materials had been given new impetus.

Such unique industrial facilitie as Shurtan gas-chemical complex, Bukhara Oil Refinery, Kungrad Soda Plant, Dekhkanabad Potash Fertilizer Plant had been built, as well as automobile plants had been constructed in Andijan, Samarkand, Tashkent and Khorezm regions.

It is impossible to imagine a modern state without a developed infrastructure. The process of enhancing national capabilities in the field of information and communication technologies and their wide application in all areas of the national economy was conducted in rapid rates. The Program for development and modernization of engineering-communication and road transport infrastructure had been drawn up and had been being implemented.

Among many other transformations the railway lines Angren-Pap with a unique tunnel through the Kamchik mountain pass, as well as Tashguzar-Baysun-Kumkur- gan line had been constructed. First high-speed train in Central Asia was launched on routes Tashkent-Samar- kand-Bukhara-Karshi. International airports had been modernized. The international logistic center based on Navoi Airport, as well as the Uzbek National Highway was established. During the years of Independence, the image of the country and its cities and villages had radically changed. In fact, the entire Uzbekistan looks like a huge construction site today. New industrial enterprises are being put into operation every year, educational and public health institutions as well as other social facilities are being constructed. Particular attention is paid to housing construction, whose scale is impressive.
On the initiative of Islam Karimov, the State Program for the construction of individual standard design housing in rural areas with allocation of preferential longterm mortgage loans was adopted in order to create modern, close to urban housing conditions for rural residents.

Thanks to Islam Karimov's consistently conducted well thought-out policy, the country's agricultural sector was fundamentally reformed. The core of the agricultural sector consists from farmer economies now. The grain independence of the country was achieved, which, along with the stable supply of flour and bread to the population of the republic, made it possible to solve the tasks of sustainable provision of the population's needs in meat, milk and meat and milk products at the expense of their own production.

In the first years of independence the new to the modern Uzbekistan foundations of a market economy were laid. The mechanism of market economic relations was launched with the creation of market infrastructure institutes and the formation of a competitive environment.

Small and private businesses have an important place in the national economy. Various privileges and preferences were established for the private entrepreneurs, as well as their access to sources of raw materials was assured. Today Uzbekistan is demonstrating dynamic developments in all spheres. In 25 years the country had become a sustainable Nation, who pays great attention to ensuring the security of its citizens and increasing their material welfare and social protection, as well as access to various types of services.

The results of the reforms based on the Islam Karimov's «Uzbek model» have repeatedly received high recognition from experts. Iveta Grigule, chairman of the delegation of the European Parliament for cooperation with Central Asian countries stated that knowing how Uzbekistan onset its development more than 25 years ago and with what legacy «the country was able to achieve almost impossible in the years of its independence» [5]

The result of the large-scale reforms has been a multiple increase of per capita income over the years of Independence during population increased one and a half time. The appearance of cities and villages has radically changed. A modern productive and non-productive infrastructure had emerged, which had become an embodiment of the principles of the «Uzbek model» of development, the ongoing reform policy for the benefit of the country, of each person. As a result, as Islam Karimov put it: «We not only managed to achieve social and political stability in the country, but also to get broad support, from the population, for the course of the reforms in the country's renewal» [6].

A clear vision of the perspective and confidence in the immeasurable strength of people gave him the right to formulate an inspiring and mobilizing target thesis: «Uzbekistan is a state with a great future». This position of the leader, naturally, influenced the psychological climate in the country, had a decisive ascendancy on the formation of a new worldview of people, it also 
had actively promoted the successful implementation of largescale reforms in all spheres of society.

A political climate encompassing a person's life and activity, psychology and spirituality was taking a shape in the country. That, in turn, determined the spiritual appearance, political legitimacy, social stability, and legal stability of the humane society that was forming in Uzbekistan.

By completely abandoning the old dogmas and stereotypes, the Islam Karimov's large-scale National Program for was developed and implemented personnel education and training. In fact, there were drastic reforms of education system based on the most up-to- date international standards. It eventually became the main priority of State policy in Uzbekistan. The branches of several leading European and Asian universities, such as the Westminster University, the Singapore Institute of Management Development, and the Polytechnic University of Turin, the Russian University of Oil and Gas, Moscow State University, the Russian Economic University, South Korean Inha University are successfully operating in the country.

Islam Karimov steered the work on the creation and implementation of fundamentally new system of upbringing and education the younger generation directly himself. That, in turn had radically changed the way of thinking and outlook the youth of the Nation. Millions of children, young men and women are receiving a high level education and training on new educational standards and curricula based on universal and national values, allowing them to find their worthy places in life, demonstrating the effectiveness of Uzbekistan's educational system, as well as its competitiveness in the international arena.

Issues of protection of motherhood and childhood, promotion of health, spiritual, moral and physical education of the younger generation had great importance for Islam Karimov. Because of this policy the State award - the Order of «Soghlom Avlod Uchun» (For a Healthy Generation) was constituted as well as the eponymous Charity Fund was established which became the first non-governmental foundation in the history of independent Uzbekistan. Moreover, the Government Program «Healthy Mother - Healthy Child» had been also developed and adopted, whose key purpose was aimed to improve the Maternal and Child Care in the country.

Eventually the international community acknowledged these efforts. The high efficiency of systemic state policy in public healthcare is proved by the fact that today an equal access to highly qualified medical services is ensured to all residents of Uzbekistan. A fundamentally new system of state-guaranteed free emergency medical care and the network of specialized clinical research medical centers had been established. Multidisciplinary, medical, prenatal and screening centers are operating in all regions of the country. The work of health care establishments is based on advanced technologies of diseases prevention, diagnostics and treatment that meet WHO standards.
Over the years of Independence, the rate of maternal and infant mortality in the country dropped more than three-fold. General health indicators of the population are increasing, including ones among children and the youth, which is especially important. The quality of life and the people's health improved. The average life expectancy of men increased from 66 to 73.5 years, and up to 76 years among women.

\section{Conclusion}

Thus, the main criterion of all reforms in the country defined by the President Islam Karimov as «Reforms are not for the sake of reforms, but for the people», had manifested itself in practice. Representatives of all nationalities in Uzbekistan without exception have absolutely equal rights guaranteed by Law. Islam Karimov steadily pursued the goal of ensuring equality for all citizens, regardless of their nationality, race, social origin, education, profession and religious confessions.

Clearly and consistently implemented Islam Karimov's principle «Uzbekistan is our common home» contributes to the preservation of peace and interethnic harmony.

Today, representatives of over 130 nations and nationalities live in peace and friendship in Uzbekistan. They enjoy all opportunities for the development of their national culture, language, folk crafts, traditions and customs. In Uzbekistan lessons within school and university Curriculums are taught in seven languages - Uzbek, Karakalpak, Russian, Kazakh, Kyrgyz, Tajik and Turkmen. Newspapers, magazines, books are being published, and television and radio programs are being broadcasted in several languages. There are about 140 republic-wide and regional national cultural centers. Such cultural and ethnic diversity is considered as an integral part of the country's life, which forms a unique and rich palette of society.

Peace and harmony in the country, interethnic and civil accord, unity and solidarity of the people of Uzbekistan are its invaluable asset, the principal achievements of independence, and the most important factor of stability in society. Uzbekistan's positive experience in strengthening interethnic relations is being studied in many countries.

Islam Karimov had raised to the level of State policy respect for the spiritual values of our people as well as preservation and development of our sacred religion, traditions, customs and invaluable historical heritage. The President had initiated the process of spiritual revival of our Nation, strengthening its selfconsciousness, recovery its historical memory, careful preservation of its enormous scientific and cultural potential, which now are nourishing the modern development of Uzbekistan.

Thanks to Islam Karimov's efforts the names of outstanding statesmen, scientists, scholars, philosophers, poets and enlighteners who had lived and worked on this land were revived. Their great legacy made up the unique phenomenon now well known as «Oriental Renaissances Islam Karimov's innovative 
power can be formulated as following: he decisively and wisely guided the process of the country's transition from one system to another. He firmly implemented reforms in all spheres of society being sure of the correctness of the chosen path.

Entire life of the First President of the Republic of Uzbekistan proved that he was a great son of Uzbek people, who devoted his entire life and fully dedicated himself to the service of the Motherland.

\section{References}

1. Levitin L (2001) Uzbekistan at a historic turning point-M, pp. 4-5.
2. Karimov IA (1997) Uzbekistan on the threshold of the 21st century: security threats, conditions and guarantees of progress. On the way to security and stability of development. V.6. - Tashkent: Uzbekistan, pp. 169.

3. Starr FS (1996) Making Eurasia Stable. Foreign Affairs 75(1): 80-92.

4. Karimov IA(1995) Uzbekistan along the path of deepening economic reforms. Tashkent: Uzbekistan, p. 27.

5. (2017) Popular Word.

6. Karimov IA (2007) Uzbekistan: 16 years of independent development. Tashkent: Uzbekistan, p. 10.

\section{Your next submission with Juniper Publishers will reach you the below assets}

- Quality Editorial service

- Swift Peer Review

- Reprints availability

- E-prints Service

- Manuscript Podcast for convenient understanding

- Global attainment for your research

- Manuscript accessibility in different formats

( Pdf, E-pub, Full Text, Audio)

- Unceasing customer service

Track the below URL for one-step submission https://juniperpublishers.com/online-submission.php 